\title{
МОРААЬ
}

\section{И ПОАИТИКА}

\author{
Фикиппов В. Р.
}

\section{СИАЬВАНУС ОАИМПИО - ПЕРВАЯ ЖЕРТВА «ФРАНСАФРИК}

\begin{abstract}
Аннотация. Использование метода исторической реконструкции позволило автору решить задачу выяснения роли Франции в организации политического убийства первого президента Республики Того Сильвануса Олимпио в 1963 г. В статье показаны причины, побудивщие Елисейский дворец к физическому устранению законно избранного президента суверенной страны: стремление к реальному суверенитету страны, установление контроля над природными ресурсами и использование природной ренты в интересах тоголезского народа, желание выйти из зоны франка, а также переориентация внешней политики Того на США и Германию в ущерб интересам бывшей метрополии. Методояогической основой исследования является системный, структурно-функииональный, сравнительно-политический подходы, методы анализа, синтеза, индукиии, дедукиии, наблюдения. Автор возлагает ответственность за политическое убийство на французские спецслужбы (агентурные сети «Франсафрик»), действовавщих по указанию секретаря по африканским делам администрачии Елисейского дворияа Жака Фоккара и под контролем президента Франции Шарля де Голял. По мнению автора именно Елисейский дворец виновен в установлении и поддержке диктаторского режима Этьена Гнассингбе в Республике Того. Исследование выполнено при финансовой поддержке РГНФ, проект № 15-01-00363, «Внешнее вмешательство во внутренние дела стран «третьего мира» в эпоху «холодной войны »: опыт многоуровневого анализа»

Ключевые слова: политика, общество, Франиия, государство, гибридные войны, иветные революиии, демократия, интересы, «Франсафрик», безопасность.
\end{abstract}

Review. The historical reconstruction approach allowed the author to solve the task of explaining the role of France in the organisation of the assassination of the first President of the Republic of Togo Sylvanus Olympio in 1963. The article shows the reasons for the Élysée Palace to physically eliminate the legally elected president of a sovereign country: aspiration for the real sovereignty of the country, control over environmental resources and the use of natural resource rents to serve the interests of the Togolese people, the desire to get out of the franc zone, as well as reorientation of foreign policy of Togo towards the United States and Germany in the prejudice of the former metropole. The methodological basis of the research are systemic, structural and functional, comparative political approaches, methods of analysis, synthesis, induction, deduction, observation. The author makes French security services (Françafrique agent nets) responsible for the assassination, acting according to the instructions of the Presidential Secretary for African Affairs Jacques Foccart and under the control of French President Charles de Gaulle. From the author's point of view, it is the Élysée Palace that 
is guilty of the establishment and support of the dictatorial regime of Gnassingbe Eyadema in the Togolese Republic.The research is conducted with financial support from the Russian Humanitarian Scientific Foundation, project No. 15-0100363 - «External intervention in the domestic affairs of the Third World countries during the Cold War: an experience of multilevel analysis».

Keywords: interests, democracy, colour revolutions, hybrid wars, state, France, society, politics, Françafrique, security.

\section{Убийство Сильвануса Олимпио - удар по движению Африки $\kappa$ политической стабильности.}

Аж. Кеннеди

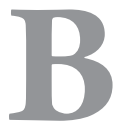
самом конце 19 столетия Германия установика протекторат наА территорией современной Тоголезской республики. Существует версия, согласно которой немецкий военный чиновник заключил с местными вожАями соответствующий контракт, причалив к месту переговоров на канонерке и продемонстрировав, чем может закончиться проявление недостаточного гостеприимства Аля местного населения. Так на карте Африки появился немецкий ТоголенА. ОАнако немецкое владычество продлимось недолго: в августе 1914 г. началась первая мировая война, германские гарнизоны в Африке быстро капитулировали и уже 30 августа 1914 г. Франция в Великобритания подписали конвенцию о разделе Того. Конвенция была подтвержАена Версальским договором 1919 г., а позже манАатами Аиги наций ${ }^{[1]}$. В результате территория немецкой колонии ТоголенА была разделена на Британское Того и Французское Того, которые в 1922 г. получили статус «подмандатных» вкаАений соответствующих европейских держав. После референдума 1957 г. территория Британского Того стала Золотым Берегом (Gold Coast) и вскоре вошла в состав Ганы, а Французское Того получимо статус автономной республики в составе Французского Содружества. Уже в это время национальным лидером тоголезцев стал Сильванус Олимпио, - оАин из самых ярких политических Аеятелей эпохи Аеколонизации Черного континента. Аанное исследование выполнено при финансовой поААержке РГНФ, проект № 15-01-00363, «Внешнее вмешательство во внутренние дела стран «третьего мира» в эпоху «холоАной войны»: опыт многоуровневого анализа»

\section{СИАЬВАНУС ОАИМПИО - ПИОНЕР АЕКОАОНИЗАЦИИ ЧЕРНОЙ АФРИКИ}

Он получил блестящее европейское образование, учился в Мондоне, Аижоне, Вене. Получив степень бакалавра экономики в $\Lambda$ ондонской школе коммерции, С. Олимпио, вернулся в 1927 г. в Африку и за- нял пост генерального агента в гомландской компа-

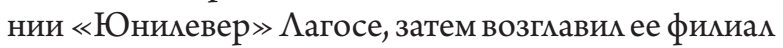
в Британском Того. Это быка почти невероятная Амя африканца карьера.

В 1941 г. С. Олимпио стал активным членом культурно-просветительской ассоциации Комитет тоголезского единства - КТЕ (Comité de l'unité togolaise - CUT). Уже тогАа он демонстрировац приверженность националистическим ценностям: говорил о необходимости воссоеАинения социоАингвистической общности эве, разАеленной политическими границами, а в 1944 г. выступил против ассимимяции тоголезцев и отмены преподавания в школах африканских языков. Он всегАа был облачен в традиционную одежАу эве, не носил европейских костюмов и не говорил на европейских языках, несмотря на то, что был полиглотом и знал шесть языков. «Мы хотим остаться тоголезцами и не же-

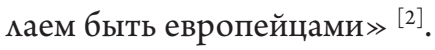

После окончания второй мировой войны, в условиях некоторой демократизации общественных отношений в африканских квази-государствах Французского СоАружества, С. Олимпио фактически превратил КТЕ в политическую партию с сильным националистическим привкусом: в 1946 г. в программу этой социально-политической структуры было вкиючено требование воссоединения общности эве и провозглашения полной независимости Того. (Это по понятным причинам совсем не понравимось власть преАержащим сосеАней Ганы.) Эти мозунги нашли подАержку большинства тоголезцев и в декабре 1946 г. КТЕ получил большинство гомосов в Территориальную ассамблею - некое подобие законодательного органа при французском губернаторе. Тем не менее, С. Олимпио стал спикером этого прообраза тоголезского парламента и незамеАлительно начал публичную борьбу за расширение прав своих соотечественников ${ }^{[3]}$.

Все это вызвало раздражение французской аАминистрации, которая прикожика все силы к тому, чтобы дискредитировать тоголезского мидера и расколоть быстро набиравший популярность КТЕ. Эта провокационная активность закончилась в 1950 г. распадом Комитета, из которого вышли преАставители северных родо-племенных сообществ, созАавших Союз вождей и народов Севера - СВНС (Union des chefs et populations du nord - UCPN). 
Аля того, чтобы расчленить ряды сторонников С. Олимпио французская аАминистрация провоцирует социальные и родо-племенные («этнические») конфмикты, стравливает отдельные социомингвистические группы межАу собой. Племенных вожАей из северных районов натравливают на социальную элиту страны юга страны, преАставители которой живут на морском побережье в столице (к этой эмите, разумеется принаАлежал и С. Олимпио) ${ }^{[4]}$. Классический прием Аиверсионной работы сетей «Франсафрик».

Раскол стал причиной неудачи КТЕ на парламентских выборах в марте 1952 г. Большинство голосов получияа коалиции СВНС и Тоголезской партии прогресса - ТПП (Parti togolais du progrès — TPТ) Николоса Грюницкого, роАственника и политического оппонента С. Олимпио. После этого послеАний преАпринял неожиАанный политический Аемарш: он уволился с поста топ-менеАжера компании «Юнилевер» и занялся исключительно политической деятельностью, используя в качестве трибуны Совет по опеке при ООН. СлеАует заметить, что вплоть Ао 1956 г. иАеолог тоголезской независимости полагац, что обретению государственного суверенитета Того Аолжно преАшествовать объединение Французского и Британского Того, подразумевая при этом политическое самоопределение и воссоеАинение в пределах оАного государства социолингвистической общности эве. Но после референдума 1956 г., в ходе которого население Британского Того проголосовало за воссоединение с Золотым Берегом, С. Олимпио во главу угла своей политической борьбы поставиц государственное самоопределение Французского Того.

Поскольку популярность молодого африканского политика быстро росла, ЕАисейский Аворец преАпринял все возможное, чтобы скомпрометировать национацьного милера. Он был обвинен в сокрытии Аоходов, нарушении вацютного законодательства и приговорен непомерному штрафу. Более того, С. Олимпио было запрещено заниматься политикой в течение пяти мет. После этого борьба за независимость Того вступила в фазу открытого противостояния: инАепенАисты - активисты КТЕ во главе с С. Олимпио - отказались участвовать в выборах 1955 г., поставив под сомнение мегитимность их результатов.

28 октября 1956 г. по итогам референдума Того получило статус автономной республики в составе Французского сообщества. Коалиционное правительство автономии было сформировано из чценов ТПП и СВНС. ОАнако С. Олимпио, используя возможности Совета по опеке при ООН, сумех Ао- биться проведения повторных выборов, и Париж вынужАен был смириться с этим решением межАународной организации. В февраме 1958 г. Франция предоставика Того статус республики, сохранив за собой право контролировать вопросы обороны, внешних связей и финансов. Новые выборы в Палату Аепутатов состоялись 27 апреля 1958 г. На сей раз КТЕ, Тоголезское народное Авижение и молодежное Авижение «ЖЮВЕНТО» в совокупности получили 70\% голосов. По итогам выборов Верховный комиссар Франции Жорж Спеналь вынужден был назначить С. Олимпио на пост премьер-министра, он покучим также портфели министра финансов и юстиции.

Как только С. Олимпио возглавия кабинет автономии, он направился в Париж на встречу с Ш. Ае Гомлем. Генерах относился к нему с симпатией, помня о том, что вишисткое правительство интернироваца молодого тоголезского политика. Но это не повлияло на результат встречи: на просьбу о преАоставцении независимости его стране, С. Олимпио получил отказ: ситуация в Алжире складывацась Аля Франции крайне неблагоприятно и Ае Гомль опасался цепной реакции.

Но уже в то время Ж. Спеналь начам плести заговор против С. ОАимпио. Известно, что он встретился с Мамой Фуссени, мидером СВНС. Если АО этого послеАний был готов искать пути компромисса с С. ОАимпио, то после этой встречи Аистанцировался и отказался от какого бы то ни было сотрудничества. МежАу тем, именно на севере страны рекрутировались солдаты в вооруженные силы Того. (Забегая впереА, заметим, что это обстоятельство, по мнению тоголезских историков, имемо трагиче-

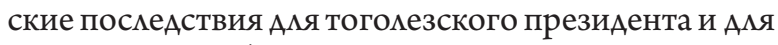
страны в цемом.)

Вступая в Аолжность премьер-министра, С. ОАимпио суть своей программы резюмировац следующим образом: «Я слелаю все возможное, чтобы Того обошлось без Франции» ${ }^{[5]}$. ОАнако он надеялся добиться независимости Того мирным путем, без крови и насимия. 16 мая 1958 г. Палата приняла решение о провозглашении независимости республики с Авухлетней отсрочкой. Это решение было принято по преАложению С. Олимпио, который счел, что такая пауза необходима Аля разработки конституции страны, реорганизации местного управления и санации финансовой системы.

27 апреля 1960 г. Тоголезская республика провозгласила независимость. На выборах президента страны 9 апремя 1961 г. харизматичный и к этому времени очень попукярный С. Олимпио набрах 99\% голосов избирателей. (Отметим: оппозиция 
бойкотировама выборы.) В тот же Аень быма принята первая Конституция Тоголезской республики, в соответствии с которой высшим законодательным органом Того стало Национальное собрание. Основной закон оформих созАание президентской республики: президент избирацся сроком на 7 мет всеобщим голосованием, назначал и смещал министров и всех Аолжностных миц, имел право законодательной инициативы, мог распустить Национальное собрание ${ }^{[6]}$.

Политическую физиономия С. Олимпио труАно оценить оАнозначно. ПриАя к власти в стране с эмбрионацьной политической культурой и слабой оппозицией, он не удержался от конструирования авторитарного режима, а в конце своего правления и культа мичности (в частности, Аень рожАения президента быц объявлен национацьным празАником и стал нерабочим днем). Уже через год после прихода к власти, в ходе президентских и парламентских выборах 1961 г. президент отстранил от участия в гомосовании практически всех своих оппонентов. Аемократический союз тоголезских народов - АСТН, новая оппозиционная политическая структура, в которую вошии ТПП и СВНС, не был Аопущен к выборам. Ааже молодежное Авижение «ЖЮВЕНТО», бывший союзник С. Олимпио, оказалось в ряАах гонимой оппозиции. А в начале 1962 г. и вовсе были запрещены все оппозиционные партии, мидеров которых обвинили в подготовке путча. Наиболее яркие оппозиционные политики были отправлены за решетку, менее заметным политическим деятелям преАоставили возможность покинуть страну. Число политзаключенных в годы правления С. Олимпио Аостигало 2,5 тыс. чел., культивировацись Аоносы, была создана политическая милиция «аблоде соАЖа», сотруАники которой (исключительно активисты правящей партии) Аолжны были искоренять инакомыслие ${ }^{[7]}$.

ОАнако в контексте нашей темы важно Аругое. Первый президент Тоголезской республики видел еАинственный путь к Аостижению реального суверенитета в обеспечении финансовой независимости страны и созАании эффективной национацьной экономики. И на этом пути он Аействительно Аобился многого. ЕАва приАя к власти, уже в 1960 г. С. Олимпио сбалансировац бюджет страны, жесткими мерами обеспечив экономию государственных средств и отказавшись от внешних заимствований. Он прекрасно понимах опасность французского неоколониализма и слелам все возможное, чтобы выйти из зоны франка. Он успел подготовить денежную реформу, которая предусматривала введение национацьной вацюты, привязанной не к французскому франку, а к немецкой марке. Тендер на изготовмение тоголезской валюты выиграла Англия, это означало разрыв отношений межАу Банком Франции и Банком Тоголезской республики. Соответствующие Аокументы должны были быть подписаны в Париже 15 января 1963 г. (Забегая впереА, отметим: презиАент Того был убит за Ава Аня Ао этого!)

По указу президента быц создан Тоголезский банк развития, призванный обеспечить финансирование наиболее значимых национальных проектов, в частности сооружение глубоководного порта в Аоме, строительство автомобильных и железных Аорог, возвеАение гиАроэлектростанция в Кпиме, созАание национамьной компании «Тогофарма» (она Аолжна была обеспечить тоголезцев Аешевыми медикаментами). Были начаты реформы в аграрном секторе экономики: госуаарство инициировало и ПоААерживало созАание сельскохозяйственных производственных и потребительских кооперативов.

Но, пожакуй, самое главное, С. ОАимпио стремился максимацьно эффективно использовать природную ренту в интересах своей страны. В отличие от большинства своих африканских коммег, он сАелал все, чтобы поставить поА государственный контроль Аобычу минеральных ресурсов, прежАе всего, фосфатов, которые составлями мьвиную Аолю экспорта республики. Он предложил французской Тоголезской компании бенинских шахт, которая еще в комониальный периоА полностью монополизировала Аобычу фосфатов, уступить правительству страны пятую часть акций Аобывающих преАприятий.

В своем стремлении максимацьно Аиверсифицировать внешнеэкономическую активность и избавиться от навязчивой опеки неАавней метрополии С. Олимпио все более демонстративно сбцижался с такими странами, как США, ФРГ и Великобритания. Отношения же с Францией, стремящейся сохранить влияние в своих бывших колониях, труАно было назвать Аружественными. При этом презиАент Того оставался сторонником политики неприсоединения к военно-политическим блокам и выступал за всемерную коорАинацию деятельности молодых африканских государств, сохраняя самые Аружественные отношения с сосеАними странами. (Исключение составляет конфмикт с Ганой, возникший после того, как президент этой страны К. Нкрума преАложиц проект объеАинения Ганы и Тоголезской республики в рамках оАного феАеративного государства. С. Олимпио назвац эту идею попыткой поглощения своей страны и отказал К. Нкруме в поААержКе, после чего ПослеАний распоряАился закрыть границу с Того.) 


\section{ПУТЧ 1963 ГОАА И УБИЙСТВО СИАЬВАНУСА ОАИМПИО}

По понятным причинам как внешняя, так и внутренняя политика тоголезской республики вызывали острое недовольство на Елисейских Полях. Шарль Ае Гомль справеАливо усматривал в Аеятельности президента Того анацогии с политикой президента Гвинеи С.А. Туре, Аемонстративно независимое поведение которого поставико под вопрос самом существование Французского содружества. Секретарь по африканским делам при президенте Франции («господин Африка») Жак Фоккар дал приказ поАконтрольным ему французским спецслужбам Аискредитировать, а при возможности физически устранить тоголезского милера. Разумеется, сделано это было с ведома (а, возможно, и по распоряжению президента Франции), поскольку послеАний придавац исключительное значение африканским делам: Ж. Фоккар, «господин Африка», кажАый вечер имем аудиенцию у Ш. Ае Гоммя ${ }^{[8]}$.

САелать это оказалось не слишком сложно, поскольку вслеАствие целого ряАа Политических ошибок и просчетов харизматичный национамьный миАер быстро терял популярность и социацьная база его режима все более заметно сужалась. Возведенная в абсолют политика жесткой экономии мишила президента подАержки государственной бюрократии. С. Олимпио не пошец навстречу требованиям служащих о ввеАении сорокачасовой рабочей неАели и систематической инАексации их Аоходов, в то время как инфмяция Аостигала 20\% в гоА, более того, он Ааже сократии ее в среАнем на 5\%, назвав это сокращение Аоходов государственным заимствованием.

Но, пожакуй, главной ошибкой президента было его стремление экономить на армии. Он ограничиц численность профессиональных военных Авумя с половиной сотнями солАат и офицеров, отказываясь Ааже обсужАать вопрос о наращивании вооруженных сил и об увеличении жалования военным. Это при том, что тоголезская армия была тогАа самой малочисленной на Черном континенте. Совсем не воинственный президент, интелмектуа С. Олимпио не собирался никого пугать и преАпомагал в дамьнейшем заменить профессионацьные войска народной милицией. Именно неАовольство военных и использовали агенты французских спецслужб Аля организации путча и свержения столь нежелательного Аля Елисейского Аворца презилента. Что очень важно, и немногочисленная армия, и жандармерия Того были подчинены французскому офицеру, прикомандированному из Парижа. Нет нужАы говорить, что он был агентом СВАК. Несмотря на это, С. Олимпио доверял ему и даже сАелал его главой военного ведомства. (Крупнейший специалист по истории французских спецслужб Франсуа-Ксавье Вершав констатировал: «КажАый глава государства находился поА опекой офицера СВАК (DGSE), который призван быи его защищать, но мог также способствовать его устранению, как это быцо в случае с С. Олимпио» ${ }^{[9]}$.)

В 1962 г. на родину из Алжира вернулись около шести сотен тоголезцев, служивших в рядах французских колониальных войск. С. Олимпио отказался принять их в ряаы тоголезских вооруженных сим: это потребовало бы многократного увеличения финансирования министерства обороны страны. Кроме того, президент обоснованно опасался проникновения в армейскую среАу мюАей, «которым чужАы были идеи тоголезской революции». КогАа сержант Этьен Гнассингбе и несколько Аесятков его сослуживцев подали рапорт о зачислении в состав тоголезской армии и производстве их в офицерский чин, президент Того заявил, что не нужАается в услугах «наемников колониализма» ${ }^{[10]}$. Правительство преАложило ветеранам французской армии еАиновременную ссуАУ Аля обустройства на родине, но те возмущенно отказались. Возмущение это бымо не спонтанным, за спиной мятежников стояли агенты французской контрразвеАки.

В ночь с 12 на 13 января 1963 г. несколько Аесятков полупьяных солдат и сержантов подъехали на грузовике к президентской резиденции, которая практически не охранялась: в ту ночь на посту нахоАились всего Ава полицейских, вооруженных стрелковым оружием. Избив охрану, путчисты принялись громить все, что попаАалось им поА руку. ОАнако за этим кажущимся хаосом скрывался хорошо проАуманный план: об этом свидетельствует тот факт, что во время этой вакханалии главарь путчистов позвонил в посольство Франции и сказал: «Мы не нашии! ${ }^{[11]}$. Наконец, в 7 часов утра мятежники выломали Аверь спальни С. Олимпио. Он попытался найти убежище на территории американского посольства, которое находилось поблизости, но не успе пересечь границу. Он был застрелен в буквальном смысле слова у Аверей посольства ${ }^{[12]}$ старшим сержантом Э. Гнассинбе, будущим марионеточным президентом Того, а фактически военным Аиктатором, поАконтрольным французским спецслужбам ${ }^{[13]}$. Убийца гордился содеянным и рассказыва об этом при всяком удобном скучае ${ }^{[14]}$. Попытка Бонито Олимпио, сына убитого президента, призвать гражАан страны к вооруженному сопротивлению мятежникам успеха не имела. Позже Аругой сын С. Олимпио - Ажиккрист - прямо обвинит «президента в черных очках в убийстве своего отца ${ }^{[15]}$. 
Якобы спонтанно, в порыве возмущения убившие законно избранного президента страны сержанты французской армии, незамеАлительно отправились в посольство Франции и поинтересовались, что же им Аелать Аальше. И посол Пятой республики в Того Анри Мазуэ порекомендовал им призвать из иммиграции политического оппонента С. Олимпио Николоса Грюницкого и преАложить ему возглавить страну.

Н. Грюницкий быи сыном немецкого офицера в отставке и африканки, дочери вожАя рода Амегаши, правившего в кантоне Гнагна ${ }^{[16]}$. Он получим хорошее образование во Франции и стал одним из наиболее ярких политиков Французского Того. В политической риторике он неизменно декларирова几 свою приверженность идее приоритета сотрудничества с метрополией. Именно поэтому этот политик при подАержке французов основал первую тоголезскую политическую партию, стал депутатом Национального собрания Франции, а затем возглавил первое правительство автономного Того. На первом заседании правительства 18 сентября 1956 г. Н. Грюницкий в своей речи, утвержАает, что его страна нужАается в помощи Франции и призывает: «За работу! Ради счастья и процветания Того через франко-тоголезскую Аружбу и сотрудничество!» ${ }^{[17]}$.

В 1958 году он бым отстранен от вцасти С. Олимпио, ушел в оппозицию, а затем эмигрировал из страны. Все это объясняет тот факт, что при подготовке мятежа 1963 г. именно он рассматривался Елисейским Аворцом в качестве приемника убитого президента Того. Вот что примечательно: незадолго до переворота Елисейский Аворец установил постоянные контакты с Н. Грюниким. Еженедельно, по субботам с Н. Грюницким встречался глава жандармерии Того, майор французской армии Жорж Мэтрие. Более того, за несколько Аней Ао путча в Котону (именно там, в Аагомее, в январе 1962 г. обосновался Н. Грюницкий, опасавшийся репрессий со стороны С. Олимпио) побывац сам Ж. Фоккар ${ }^{[18]}$.

\section{«ВТОРАЯ РЕСПУБАИКА В ТОГО}

14 января 1963 г. на засеАании Повстанческого комитета (так назвали себя путчисты) бымо решено обратиться к Н. Грюницкому с просьбой сформировать правительство. Мятежники отправили в Аагомею за своим избранником самолет и уже вечером того же Аня Н. Грюницкий прибыи в $\Lambda$ оме, гАе незамедлительно был назначен президентом Того и ему было предложено сформировать Временное правительство ${ }^{[19]} .17$ января оно было сформиро- вано, а президент и глава кабинета объявиц, что виАит свою задачу в организации свободных выборов и принятии новой Конституции ${ }^{[20]}$.

Опасаясь народного гнева, мятежники вывезки тело С. Олимпио в Аагомею и предали земле в городке Агу. Н. Грюницкий прибыл на похороны и произнес речь, посвященную выдающимся заскугам убитого президента ${ }^{[21]}$. При этом его сестра, жена С. Олимпио Аина не пожелала вернуться в Того, где во главе страны оказался её родной брат. Она осталась в Аагомее, гАе и скончалась в Котону в сентябре 1964 г., ее похоронили в Агу рядом с мужем ${ }^{[22]}$.

Почти все молодые африканские страны выразили возмущение убийством оАного из самых известных и ярких кидеров и идеологов панафриканизма. Правительство Н. Грюницкого на какое-то время оказалось в межАународной изоляции, однако в июне 1963 г. новый режим быи признан 42 странами, в том числе СССР и США.

Париж приветствовац путчистов, Ш. Ае ГомАь не постеснялся выразить УАовметворение по поводу прихода Н. Грюницкого к власти ${ }^{[23]}$. БАизкий к генералу политик Ален Пейрефит вспоминает, что после заседания Совета министров 15 января 1963 г. тот бросил такую фразу: «Этот Грюницкий очень УАобоварим Амя нас, хотя и недостаточно энергичен.... ${ }^{[24]}$.

Последний вполне оправАал ожиАания презиАента Пятой республики. ЕАва приАя к вмасти, он вернул Того на стезю самого тесного сотрудничества с Францией и слелал все возможное аля возвращения в страну французского капитала. 10 июля 1963 года было заключено соглашение о сотрудничестве с Францией в области обороны, экономики, финансов и образования. В соответствие с Аостигнутыми договоренностями французская армия взяла на себя оборону страны ${ }^{[25]}$. Это фактически означало утрату суверенитета страны, все Аостигнутое С. Олимпио бымо разрушено ${ }^{[33]}$.

Н. Грюницкий просидел в президентском кресле четыре года и эти годы не были временем процветания и покоя тогомезцев. Интемлектуал и миберал, он освободил политических закмюченных и разрешил деятельность оппозиционных партий. Но страна уходимо из его рук. Острое политическое соперничество партийных структур ${ }^{[34]}$, основанных в основном на трайбалистской солидарности, противостояние многочисленных социолингвистических общностей дестабилизировало ситуацию.

9 апреля 1963 г. был раскрыт заговор под преАводительством Теофиля Мальи, министра внутренних дел в правительстве С. Олимпио. Пять заговор- 
щиков быми арестованы, самому Т. Мамьи удамось бежать в Нигерию ${ }^{[26]}$. ГоА спустя, в 1964 году, начамись племенные раздоры в армии, с большим трудом уаалось предотвратить вооруженные столкновения. В ноябре 1966 г. конфмикт Н. Грюницкого с вицепрезилентом Антуаном Меачи перерос в массовые выступления в переворота была пресечена армией. Аиберальный проект «Второй республики» проваликся, режим Н. Грюницкого не устраивац ни политическую элиту, ни нарожАавшуюся национальную буржуазию, ни армейскую верхушку. Но, самое главное, он утратил доверие Елисейского Аворца.

\section{ПУТЧ 1967 ГОАА. УСТАНОВАЕНИЕ АИКТАТУРЫ ЭТЬЕНА ГНАССИНГБЕ}

В обстановке затяжного кризиса в политический процесс вновь вмешалась Франция. Ж. Фоккар вновь посетил Того и вновь воспользовался услугами Г. Эйадемы (Этьена Гнассингбе), который к этому времени стаА поАполковником и возглавил Генеральный штаб тоголезской армии. «Господин Африка» остановик свой выбор на сержантеубийце полполковнике Г. Эйадеме и убеАим Елисейский Аворец сАелать ставку именно на него. Ж. Фоккару пришлось убежАать и своего избранника, который вполне осознавал свою серость и полную непригоАность к политической Аеятельности ${ }^{[27]}$. И, тем не менее, 13 января 1967 г. он возглавил очередной путч и захватил власть. Поначаку в политической риторике этого вояки звучали обещания провести в стране всеобщие выборы, однако к апрелю разговоры о них стихли. Э. Г. Эйадема разогнац Комитет национального примирения и провозгласил себя президентом. Политические партии на Аолгое время были запрещены, а ставший генералом сержант воссеАац в президентском кресле вплоть Ао своей смерти от сердечного приступа в 2005 г.

Э.Г. ЭйаАема, родившийся в семье мелкого торговца, скверно учился в школе, зато стал чемпионом страны в местном виде спорта - борьбе мальчиков нагишом в жиАкой глине. После школы он служил во французской армии в Аагомее (нынешний Бенин), участвовал в подавлении сопротивления патриотов в Индокитае, Алжире, Вьетнаме. Этот сомАафон, убийца и политический преступник правил страной 38 мет. Оппозиции в стране практически не было: президент скармиивал оппозиционных политиков крокодикам ${ }^{[28]}$. Но это был именно тот правитель Того, который был нужен Елисейскому Аворцу. «Ушел Аруг Франции, который Аһя меня был и мичным Аругом» ${ }^{[29]}$ Аекларировал президент
Пятой республики Жак Ширак, узнав о смерти марионеточного президента.

Трагикомическая фигура нового президента мало у кого вызывала почтение. В военной фуражке с невероятно высокой тульей, увешанный орАенами и аксемьбантами он походил на персонаж из мюзикма. Покуграмотный глава государства зачитывал собственные указы по слогам. Впрочем, от него никто и не требовац проявления госуАарственной муАрости: змые языки говорили, что страной по телефону из Парижа управмял «господин Африка»,Ж. Фоккар. Осторожный и хитрый Э. Г. Эйадема в полной мере использовал сети «Франсафрик» Аля упрочения режима Аичной власти, но наряду с этим плен и собственную сеть матентных политических, военных и бизнес связей на Черном континенте. ЕАинственно, что французские спецслужбы доверили тоголезскому президенту полностью и с чем он прекрасно справмялся, - это была борьба с противниками режима. Их, якобы, живьем скармливами крокодилам, обитавшим в парке президентского Аворца.

Впрочем, если возникала реальная угроза правмению одиозного Аиктатора, французские покровители вмешивались незамедлительно. Так случияось посме того, как в 1979 г. в Гане к власти пришел Ажерри Ролингс, близкий Аруг клана Олимпио. Э. Г. Эйадема увидел в этом угрозу Аля себя и своего режима и слелал все возможное, чтобы новый глава Ганы оказался в полной изоляции. КогАа в 1985 г. в столице страны произошли несколько террористических актов, спецскужбы Того во всем обвинили Жимькри Олимпио, одного из сыновей С. Олимпио (он был заочно приговорен к смертной казни) и агентов Ганы. Назревал вооруженный конфмикт, и в ситуацию поспешила вмешаться Франция. С помощью французских войск граница с Ганой была закрыта.

Тоголезский узурпатор пользовался покровительством президентов Пятой республики от Ш. Ае Голмя до Ж. Ширака. В июле 1999 г. состоялся официальный визит последнего в Того; возвратившись в Париж президент Франции обвинил правозащитную организацию Amnesty International в том, что она распространяет вредоносные слухи о режиме Э. Г. Эйадемы. Париж попросил Евросоюз перевернуть страницу кровавого насилия девяностых годов и возобновить экономическую помощь, столь необходимую Аля Того.

БАагодаря протекции Елисейского Аворца этот бывший сержант стал чменом-учредителем и президентом Экономического сообщества западноафриканских государств - ЭКОВАС (Communauté 
Économique des États de l'Afrique de l'Ouest CEDEAO) в 1977-1978, 1980-1981, 199 гг. Разумеется, он быц безотказным проводником интересов Франции в этой влиятельной межАународной организации ${ }^{[30]}$.

Неусыпная опека Парижа объясняет и тот факт, что приемником Э. Г. Эйадемы на посту президента Того стал его сын, столь же преданный Франции, как и его отец. Таким образом, ревнительница Аемократических традиций - Франция - способствовала формированию династии Гнасингбе в якобы суверенном государстве - Тоголезской республике. После смерти Э.Г. Гнассингбе высшие чины армии Того просто провозгасили новым президентом Того его сына Фора Эсозимна Гнассингбе.

Некоторые африканские мидеры усмотрели в этом военный переворот: по тоголезской конституции новым президентом страны должен был стать спикер пармамента Фамбаре Натчаба Уаттара. Но он в момент смерти узурпатора быи в во Франции, его просто не пустили в Того, закрыв границы страны на неопределенный срок. А тем временем генералитет поспособствовац тому, что Ф.Э. Гнассингбе на внеочередной сессии пармамента выбрали спикером и изменили конституцию, отменив положение о проведении внеочередных выборов в течение четырех месяцев после смерти президента. Сын Аиктатора получия от послушного парламента право занимать президентский пост Ао слеАующих очередных выборов.

Убийство первого президента Того, спланированное и осуществленное агентами «Франсафрик», прервало нормальный хоА истории маленькой, очень бедной африканской страны и отбросило ее на многие годы назаА. ЕАисейский Аворец, нисколько не сомневаясь, пошем на это политическое убийство и попрание норм межАународного права исключительно Аля того, чтобы сохранить в целости свою вотчину на Черном континенте. Шарль Ае Гомль, в условиях распада колониальной империи Франции провозгаасивший принцип «Уйти, чтобы остаться», конструировал Французское соАружество огнем и мечом. Он не желал позволить той или иной стране, тому или иному мидеру даже помыслить о реальном суверенитете и избавлении от навязчивой опеки бывшей метрополии.

За «Франсафрик» тянется Алинный шлей преступлений. Это уроАливое Аитя рожАалось в муках алжирской войны 1954-1962 гг. ТогАашний глава МВА и будущий президент Франции Франсуа Миттеран санкционировал применение самых жестких методов против борцов за независимость. Война унесла жизни 300 тыс. алжирцев. В 1955 г.
Франция развязывает войну в Камеруне, чтобы уничтожить патриотов, объединившихся в Союз народов Камеруна. Аидер этого Союза - Рубен Ум Ниобе бым убит французскими карателями в 1958 г. Война продолжалась до 1970 г., жертвами репрессий по разным Аанным стали от 100 Ао 400 тыс. чел. Убийство Симьвануса Олимпио в 1963 г. и конструирование в Того кровавой диктатуры Этьена Гнассингбе положимо конец суверенитету этой страны. В 1964 г. произошел военный переворот в Габоне: ставленник Франции президент

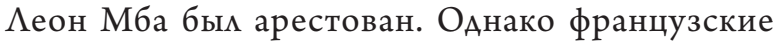
Аесантники уже через Ава Аня вернули его в президентское кресло. Вскоре, в 1967 г. А. Мба умирает, а его место при подАержке французов занимает вице-президент Омар Бонго. КогАа в начале 1990-х гг. кресло поА ним закачалось, в Габон вновь прибыли французские солдаты, чтобы подАержать «Аруга Франции». Убийство в Париже в 1965 году лидера марокканской оппозищии Бен Барка также было Аелом французских спецскужб. Разжигание гражданской войны в Нигерии в 1967-1970 гг. и поААержка сепаратистов Биафры на совести Жака Фоккара. Во время гражАанской войны в Бурунди в 1970-1972 22. Франция снабжала оружием путчистов из общности $m y m c u$, что привело к геноциду: около 200 тыс. хуту были убиты и не менее ста тысяч стали беженцами. В 1978 г. французский «король наемников» Боб Аенар с полусотней боевиков высадияся на Коморских островах и сверг правительство А. Суалиха (он национализировал земли французских катифундистов). В 1987 г. в Верхней Вольте (Буркина Фасо) был убит президент страны Томас Санкара. Путч организовац Ж. Фоккар, а исполнителем стал Блез Компаоре марионетка Парижа. В 1989 г. Жак Фоккар подготовия вторжение наемников поА преАводительст-

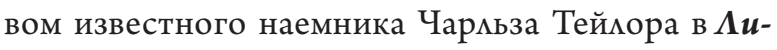
берию. Жертвами развязанной ими войны стали около 250 тыс. человек, около 2 млн. миберийцев стали беженцами. В 1990-1994 гг. французские спецскужбы разжигают конфликт между хуту и тутси в Руанде. За 100 Аней геноциАа погибли не менее 800 тыс. человек. В 1997 г. в Конго (Браззавиле) агентурные сети Шармя Паскуа и Жака Фоккара привели диктатора Аени Сассу-Нгессо; созАанный им военный режим прибег к чудовищным репрессиям. В 1991 г. боевики из ОбъеАиненного Революционного Фронта, являвшегося Аочерней структурой «Франсафрик», вторглись в Сверра-Аеоне из Аиберии. Франция активно подАерживала наемников, поставляя им оружие. Война за миберийские алмазы продолжалась 11 
мет, результатом этой бойни стали 75000 человек. В 1997 г. Францию потряс политический скандац, получивший название «Анголагейт». Сын презиАента Франсуа Миттерана Жан-Кристоф, бывший министр внутренних Аел Франции Шарль Паскуа и Ар. в 1993-1998 гг. в обхоА санкций ООН организовали масштабные поставки оружия в Анголу, гАе в это время шла кровопролитная гражданская война. В 1974 г. президент Нигера Амани Аиори заявиц, что его страну не устраивают преАложенные Францией цены за уран и незамеАлительно стал жертвой путчистов. В 1999 г. президент МамаАу ТанАжа преАложил Парижу пересмотреть условия закупок урана и раздекил участь преАшественника. В 2010 г. президент Кот-д’Ивуара Аоран Гбагбо обвинил французские спецслужбы в организации заговора с целью отстранения его от власти. После этого французский спецназ штурмом взял президентский Аворец, арестовац президента и переАах его в руки вооруженной оппозиции поА преАводительством Алассана Уаттары. Франция инициировака вторжение НАТО в Аивию в марте 2011 г. и французская авиация стала ударной силой амьянса в этой кровавой бойне. Соперничество с Пекином в праве закупать уран по монопольно низким ценам стало причиной военного вторжения Франции в Мали и полномасштабной войны на севере этой страны в 2013 г. Борьба за уран побудила в 2014 г. ЕАисейский Аворец спровоцировать меж- конфессиональный конфмикт в Центральноафриканской республике и использовать его как повоА А^я военного вторжения в эту страну.

В электорахьной риторике французские президенты неизменно обещают покончить с помитикой «Франсафрик». Вспомним: Николя Саркози накануне прошлых президентских выборов во Франции говорих о своей готовности отказаться от этой непригляАной политической практики. А потом были штурм президентского Аворца Иоран Гбагбо в Кот-А'Ивуаре и ракетные уАары по мирному населению Аивии. 13 октября 2012 года, новый президент Франции Франсуа О $\Lambda^{-}$ манА, выступая переА Аепутатами Национацьного собрания Сенегама в Аакаре, говориц о том, что впреАь Париж будет Аискутировать с африканскими государствами на равных, а практика неокомониализма уйдёт в прошлое. «Времена того, что называли «Франсафрик», прошии» ${ }^{[31]},-$ заяви он. Теперь он обещает, что времена эти пройдут когАа-нибудь ... 27 ноября 2014 г. в канун саммита МежАународной организации франкофонии в Сенегале, Ф. Омланд неукмюже объяснял, почему Французские Аесантники эвакуировали политического преступника Б. Компаоре, спасая его от правосуаия в Буркина-Фасо. И в который раз объявиц, что «Ани вмешательства Франции в дела бывших комоний сочтены» ${ }^{[32]}$. Свежо преАание, Аа верится с трудом...

\section{БИБАИОГРАФИЯ}

1. Того // Африка. Энциклопедический справочник. М., Институт Африки РАН. ИзАательство «Энциклопедия $\gg .2010$. Т.

2. С. 776. 2. Кривушин И. В. Симьванус Эпифанио Омимпио // История Африки в биографиях. М., РГГУ. 2012. C. 629-632.

3. Dyke F. A. Sylvanus Epiphanio Olympio. Libérateur du Togo: Esse biografique. Lome, 1989.

4. Pesnot P. Premier coup d'état en Afrique-Assassinat de Sylvanus Olympio: Monsieur X raconte... - http:// www.soninkara.org/forum-soninkara/cheikh-anta-diop-frantz-fanon-cheikh-toure-etc-f33/topic715. html\#p8218

5. Olympio S. Quelque discurs importans du président Sylvanus Olympio. Lome, 1992.

6. Adjavon R. Naissance d un état africain: Le Togo, territoire pilote. Lome, 1989. P. 54.

7. Lawrance B. N. Olympio, Sylvanus Epiphanio / / Dictionary of African Biography. V. 6. Oxford, 2012. P. 33-36.

8. Pesnot P. Premier coup d'état en Afrique-Assassinat de Sylvanus Olympio: Monsieur X raconte ... - http: // www.soninkara.org/forum-soninkara/cheikh-anta-diop-frantz-fanon-cheikh-toure-etc-f33/topic715. html\#p8218

9. Verschave F.X. La Françafrique. Retranscription de conférences-débat données par F.X. Verschave, président de Survie de 1995 à 2005 - http://survie.org/francafrique/article/la-francafrique.

10. Белаш В. Президент всего Того // Коммерсант-Власть. 2005. № 6. С. 54.

11. Pesnot P. Premier coup d'état en Afrique-Assassinat de Sylvanus Olympio: Monsieur X raconte... - http:// www.soninkara.org/forum-soninkara/cheikh-anta-diop-frantz-fanon-cheikh-toure-etc-f33/topic715. html\#p8218

12. Тушин Р. Кто кого в Того http://www.gazeta.ru/politics/2005/04/24_a_274949.shtml

13. Agbobli A. K. Sylvanus Olympio, un destin tragique. Dakar; Lome, 1992. P. 127. 
14. Pesnot P. Premier coup d'état en Afrique-Assassinat de Sylvanus Olympio: Monsieur X raconte... - http:// www.soninkara.org/forum-soninkara/cheikh-anta-diop-frantz-fanon-cheikh-toure-etc-f33/topic715. html\#p8218

15. Mas M. De la présidence Eyadéma à la dynastie Gnassingbé — http://www1.rfi.fr/actufr/articles/062/ article_33840.asp

16. Николас Грюницкий. Аюди и события // Новое время. 1963. № 4. С. 31.

17. Nicolas Grunitzky. Biographies des députés de la IVe République — http://www.webcitation.org/6GebxTkCw

18. Glaser A., Smith S.. Ces messieurs Afrique // Le Paris-Village du continent noir. Paris, Calman Levy. 1992.

19. Coment Le Togo est tombe dans les griffes de la francafrique // http://www.diastode.org/Echos/invit5873. html

20. Николас Грюницкий. Аюди и события // Новое время. 1963. № 4. С. 31.

21. La Deuxième République // http://www.diastode.org/Droits/tete1c.html

22. Biographie de Sylvanus Epiphanio Kwami OLYMPIO // https://sylviocombey.wordpress.com/les-grandsdisparus/

23. Coment Le Togo est tombe dans les griffes de la francafrique // http://www.diastode.org/Echos/invit5873. html

24. Coment Le Togo est tombe dans les griffes de la francafrique // http://www.diastode.org/Echos/invit5873. html

25. Того // Ежегодник БСЭ. 1964. С. 364.

26. La Deuxième République // http://www.diastode.org/Droits/tete1c.html

27. Kuadjose L. C. La date du 13 janvier dans l'histoire du Togo. Diaspora Togolaise pour la Democratie (12 janvier 2006) - https://www.diastode.org/Echos/invit8097.html

28. Белаш В. Президент всего Того // Коммерсант-Вцасть. 2005. № 6. С. 54.

29. Mas M. De la présidence Eyadéma à la dynastie Gnassingbé - http://www1.rfi.fr/actufr/articles/062/ article_33840.asp

30. Étienne Eyadéma Gnassingbé // Encyclopedie larousse - http://www.larousse.fr/encyclopedie/ personnage/

31. ОмланА: Африка — будущее мировой экономики — http://www.vz.ru/news/2012/10/13/602344.html

32. Омланд призвал мидеров Африки не цепляться за власть -http://www.bbc.co.uk/russian/rolling_ news/2014/11/141127_rn_hollande_france_africa

33. Маноймо А. В. Информационно-психологические технологии разрешения современных конфликтов. // ВАасть.-2008.—№ 5.- С.27-30.

34. Манойло А. В. Несиловое регулирование межАународных конфликтов. Культурно-цивилизационные парадигмы. // Космополис. —2008.—№ 2.— С.168-174.

35. БуАаев А. В. Сравнительный анализ «мягкой силы» во внешней политике России и Бразилии. // Аатинская Америка. 2014. № 4. С. 24-31

36. Манойло А. В. Гибридные войны и цветные революции в мировой политике // Право и политика.2015. - 7.—C. 918-929. DOI: 10.7256/1811-9018.2015.7.15832.

37. Косенко С. И. Фактор «мягкой силы» в кумьтурной Аипломатии Франции // МежАународные отношения. — 2015.— 2.— С. 197-208. DOI: 10.7256/2305-560Х.2015.2.10167.

38. А. Э. Галумов Перспективы публичной Аипмоматии и имиАжа ЕС в России // МежАународные отношения. - 2012.- 1.- С. 118-127.

39. А.А. Косоруков Основные детерминанты процесса принятия внешнепомитических решений // Национальная безопасность / nota bene. - 2012. - 4.- С. 29-46.

\section{REFERENCES (TRANSLITERATED)}

1. Togo // Afrika. Entsiklopedicheskii spravochnik. M., Institut Afriki RAN. Izdatel'stvo 'Entsiklopediya' 2010. T.

2. S. 776. 2. Krivushin I. V. Sil'vanus Epifanio Olimpio // Istoriya Afriki v biografiyakh. M., RGGU. 2012. S. 629-632.

3. Dyke F. A. Sylvanus Epiphanio Olympio. Libérateur du Togo: Esse biografique. Lome, 1989.

4. Pesnot P. Premier coup d'état en Afrique-Assassinat de Sylvanus Olympio: Monsieur X raconte ... - http:// www.soninkara.org/forum-soninkara/cheikh-anta-diop-frantz-fanon-cheikh-toure-etc-f33/topic715. html\#p8218 
5. Olympio S. Quelque discurs importans du président Sylvanus Olympio. Lome, 1992.

6. Adjavon R. Naissance d un état africain: Le Togo, territoire pilote. Lome, 1989. P. 54.

7. Lawrance B.N. Olympio, Sylvanus Epiphanio // Dictionary of African Biography. V. 6. Oxford, 2012. P. 33-36.

8. Pesnot P. Premier coup d'état en Afrique-Assassinat de Sylvanus Olympio: Monsieur X raconte ... - http:// www.soninkara.org/forum-soninkara/cheikh-anta-diop-frantz-fanon-cheikh-toure-etc-f33/topic715. html\#p8218

9. Verschave F.X. La Françafrique. Retranscription de conférences-débat données par F.X. Verschave, président de Survie de 1995 à 2005 - http://survie.org/francafrique/article/la-francafrique.

10. Belash V. Prezident vsego Togo // Kommersant-Vlast’. 2005. № 6. S. 54.

11. Pesnot P. Premier coup d'état en Afrique-Assassinat de Sylvanus Olympio: Monsieur X raconte... - http:// www.soninkara.org/forum-soninkara/cheikh-anta-diop-frantz-fanon-cheikh-toure-etc-f33/topic715. html\#p8218

12. Tushin R. Kto kogo v Togo http://www.gazeta.ru/politics/2005/04/24_a_274949.shtml

13. Agbobli A. K. Sylvanus Olympio, un destin tragique. Dakar; Lome, 1992. P. 127.

14. Pesnot P. Premier coup d'état en Afrique-Assassinat de Sylvanus Olympio: Monsieur X raconte ... - http:// www.soninkara.org/forum-soninkara/cheikh-anta-diop-frantz-fanon-cheikh-toure-etc-f33/topic715. html\#p8218

15. Mas M. De la présidence Eyadéma à la dynastie Gnassingbé — http://www1.rfi.fr/actufr/articles/062/ article_33840.asp

16. Nikolas Gryunitskii. Lyudi i sobytiya // Novoe vremya. 1963. № 4. S. 31.

17. Nicolas Grunitzky. Biographies des députés de la IVe République — http://www.webcitation.org/6GebxTkCw

18. Glaser A., Smith S.. Ces messieurs Afrique // Le Paris-Village du continent noir. Paris, Calman Levy. 1992.

19. Coment Le Togo est tombe dans les griffes de la francafrique // http://www.diastode.org/Echos/invit5873. html

20. Nikolas Gryunitskii. Lyudi i sobytiya // Novoe vremya. 1963. № 4. S. 31.

21. La Deuxième République // http://www.diastode.org/Droits/tetelc.html

22. Biographie de Sylvanus Epiphanio Kwami OLYMPIO // https://sylviocombey.wordpress.com/les-grandsdisparus/

23. Coment Le Togo est tombe dans les griffes de la francafrique // http://www.diastode.org/Echos/invit5873.html

24. Coment Le Togo est tombe dans les griffes de la francafrique // http://www.diastode.org/Echos/invit5873. html

25. Togo // Ezhegodnik BSE. 1964. S. 364.

26. La Deuxième République // http://www.diastode.org/Droits/tetelc.html

27. Kuadjose L. C. La date du 13 janvier dans l'histoire du Togo. Diaspora Togolaise pour la Democratie (12 janvier 2006) - https://www.diastode.org/Echos/invit8097.html

28. Belash V. Prezident vsego Togo // Kommersant-Vlast'. 2005. № 6. S. 54.

29. Mas M. De la présidence Eyadéma à la dynastie Gnassingbé — http://www1.rfi.fr/actufr/articles/062/ article_33840.asp

30. Étienne Eyadéma Gnassingbé // Encyclopedie larousse - http://www.larousse.fr/encyclopedie/ personnage/

31. Olland: Afrika — budushchee mirovoi ekonomiki — http://www.vz.ru/news/2012/10/13/602344.html

32. Olland prizval liderov Afriki ne tseplyat'sya za vlast' -http://www.bbc.co.uk/russian/rolling_ news/2014/11/141127_rn_hollande_france_africa

33. Manoilo A.V. Informatsionno-psikhologicheskie tekhnologii razresheniya sovremennykh konfliktov. // Vlast'.-2008.—№ 5. - S.27-30.

34. Manoilo A. V. Nesilovoe regulirovanie mezhdunarodnykh konfliktov. Kul'turno-tsivilizatsionnye paradigmy. // Kosmopolis. - 2008.—№ 2.—S.168-174.

35. Budaev A. V. Sravnitel'nyi analiz 'myagkoi sily' vo vneshnei politike Rossii i Brazilii. // Latinskaya Amerika. 2014. № 4. S. $24-31$

36. Manoilo A. V. Gibridnye voiny i tsvetnye revolyutsii v mirovoi politike // Pravo i politika._ 2015. - 7._ C. 918-929. DOI: 10.7256/1811-9018.2015.7.15832.

37. Kosenko S. I. Faktor 'myagkoi sily' v kul'turnoi diplomatii Frantsii // Mezhdunarodnye otnosheniya. 2015.—2.—C. 197-208. DOI: 10.7256/2305-560X.2015.2.10167. 
38. A.E. Galumov Perspektivy publichnoi diplomatii i imidzha ES v Rossii // Mezhdunarodnye otnosheniya.2012.-1.- C. 118-127.

39. A.A. Kosorukov Osnovnye determinanty protsessa prinyatiya vneshnepoliticheskikh reshenii // Natsional'naya bezopasnost' / nota bene. - 2012. - 4. - C. 29-46. 